\title{
ON GRAIN, BONES, AND KHABUR COLLAPSE*
}

\author{
O ZIARNIE, KOŚCIACH I KRYZYSIE OSADNICZYM \\ NAD HABUREM
}

\section{Rafał Koliński}

Instytut Prahistorii, Uniwersytet im. Adama Mickiewicza ul. Św. Marcin 78, 61-809 Poznań, Poland

\begin{abstract}
A hypothesis on the total collapse of the settlement in Northern Syria at the end of the third millennium BC, put forward in 1993 by Harvey Weiss and his team, is one of the most disputed issues in the protohistoric archaeology of North Mesopotamia. Today it is obvious that the crisis has not been as general as Weiss believed. Also his original explanation of the cause of this event (volcano eruption in the Near East) is generally doubted. The author discusses the present state of knowledge of the archaeology of this period as well as proxy data used for environmental reconstructions, because an environmental crisis is considered to be the most likely cause of the decline in settlement. One of the aims of the paper is to propose new sources for environmental proxies, which may help in the formulation of a more accurate reconstruction of environmental trends in the Near East in general.
\end{abstract}

The archaeological mission of the Yale University directed by Harvey Weiss, working at Tell Leilan in north-eastern Syria, observed a continuous settlement covering the first half of the $3^{\text {rd }}$ millennium BC and about three centuries of the second (Weiss 1990a, 1990b, 1990c; Weiss et al. 1993: 996-1002). It came to an abrupt end leaving an abandoned city, with some buildings still under construction (Weiss 2002). The site has been resettled in the $19^{\text {th }}$ century BC, when, under the traditional name Shehna, it served as a capital of a regional state of Apum (Weiss 1985). The period of the abandonment, about 300 years long, dubbed by the excavator "The Khabur hiatus 1", covers the postAkkadian period (or Eearly Jazireh V, ca. 2150-2000 BC and Middle Bronze I period (Old Jazireh I, ca. 2000-1800 BC) (Weiss - Courty 1993: 141-142).

An interpretation of the causes of this abandonment was proposed for the first time in 1993 (Weiss et al. 1993), and elaborated further in subsequent years by Harvey Weiss,

\footnotetext{
*Na wyraźne życzenie Autora akceptujemy wyjątkowo poniższą formę przypisów i bibliografii, nieco odbiegającą od norm przyjętych zwykle w FPP (uwaga Redakcji).
} 
Marie-Agnes Courty and the others (Weiss 2000a, 2000b, 2002; Weiss - Courty 1993; Weiss - Bradley 2001; Courty - Weiss 1997; Courty 1994, 1998, 1999, 2001, 2002)1. According to this hypothesis, the abandonment was caused by the abrupt deterioration of the environmental conditions at the site and in its vicinity. Deposits of ashes containing tephra-like particles uncovered in an abandoned building of Leilan II period (Early Jazirah IV, or Akkadian in older, historical terminology, ca. 2300-2150 BC) led to the conclusion that the change of environment was triggered by a volcanic eruption, which caused wild fires and an increase of dust and volcanic ash content in the air (Courty 1994; Courty - Weiss 1997; Weiss - Courty, Weiss et al. 1993: 999-1003). A prolonged screening of the earth's surface from the sun operation caused a drop of temperature and triggered the aridification of climate, which subsequently forced the population of the area to look for more favorable conditions. This assumed migration resulted in the abandonment of nearly all settlements in a previously densely settled agricultural area of the so called Khabur Triangle, dubbed by Weiss "the Khabur collapse" (Weiss - Courty 1993: 142-145; Weiss et al. 1993: 1001-1002). Subsequent work of Weiss demonstrated that the change in conditions in the Khabur area of north-eastern Syria is a part of a phenomenon which is observable in the large areas of the northern hemisphere (at least from Portugal to the Indus valley) at about the same time (Weiss 2000a, 2000b, 2002; Weiss - Bradley 2001).

It has to be noted that Tony Wilkinson proposed a different interpretation of causes leading to the abandonment of the Khabur area in 1997 (Wilkinson 1997, 2003: 126). In his opinion, the crucial point was the deterioration of the agrarian conditions caused by prolonged overexploitation of the agricultural land, suggested by alleged attempts to restore fertility of the land by using earth from the settlements as manure. The climatic changes of the late $3^{\text {rd }}$ millennium $\mathrm{BC}$ provided only the final push to the already unstable agricultural economy of local settlements.

The recent decade of research resulted in retrieving new evidence and reinterpretation of data available previously, forcing to question some basic points of both quoted hypotheses.

\section{SETTLEMENT ABANDONMENT (FIG. 1)}

The aim of both quoted hypotheses was to explain an alleged large scale abandonment of settlements located in the Khabur triangle area. But already in 1993, when the hypothesis of Harvey Weiss was published, the fact of large scale abandonment was disputable. Firstly, sir Max Mallowan discovered substantial evidence of the "Third Dynasty of Ur period" settlement when excavating at Tell Brak in 1937 and 1938, featuring mainly domestic structures, but notably also an adaptation of the earlier "Fort of

\footnotetext{
${ }^{1}$ For the most recent summaries see: Zettler 2003: 17-29, Rutkowski 2006: 11-30, 255-279 (in Polish); Koliński 2007.
} 
Naram-Su'en" (Mallowan 1947: 25-26, 28-29 and Pl. LIX, LXIV). Secondly, the so called Tish-atal inscription at the Louvre (Wilhelm 1998), as well as some Ur III period sources of Southern Mesopotamia (Owen 1992) pointed to a significant political position held in the North by the kings of Urkesh, identified soundly with Tell Mozan. Thus it was clear that the abandonment had not been as complete as suggested by Weiss.

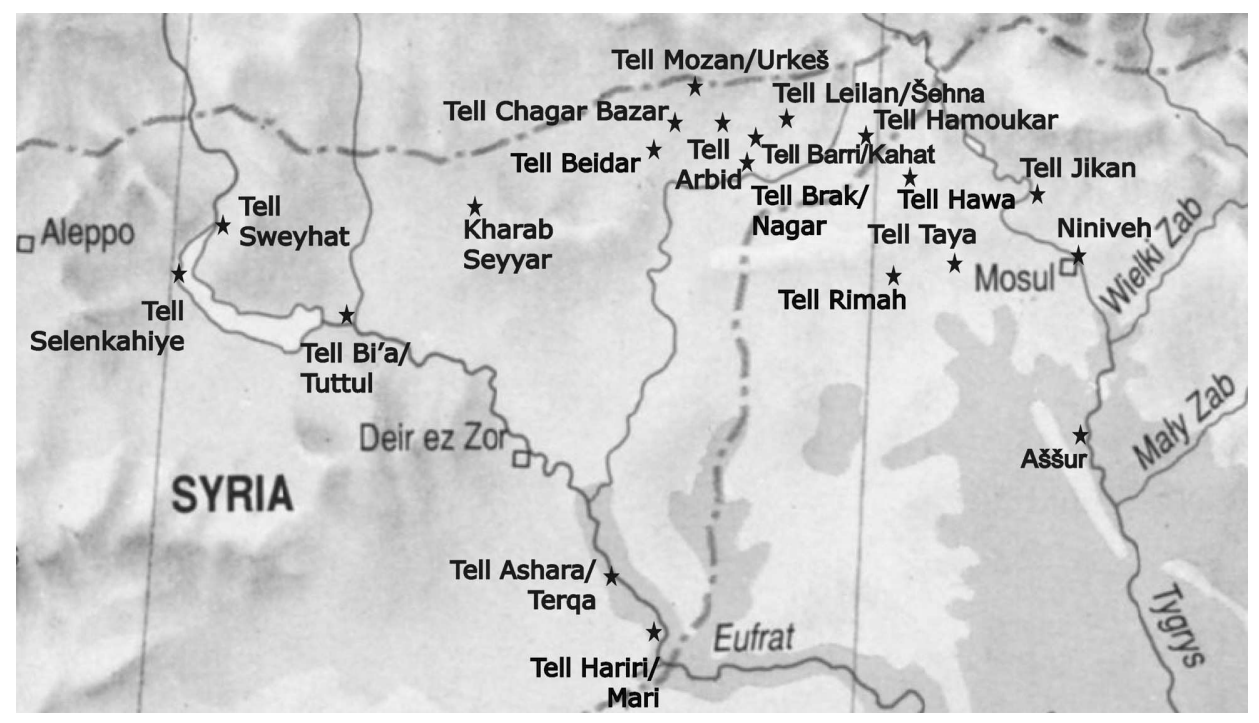

Fig. 1. Excavated sites of the terminal $3^{\text {rd }}$ millennium BC in North Mesopotamia (drawn by the author)

Ryc. 1. Zbadane stanowiska archeologiczne z osadnictwem ze schyłku III tysiąclecia p.n.e. (rys. autora)

Recent work at Tell Brak, published finally in 2003 (Oates - Oates 2001; Oates 2001), as well as continuous excavations at Tell Mozan, confirmed that both these sites constituted significant urban centers ruled by local dynasties of Hurrian origin during the late $22^{\text {nd }}$ and most of the $21^{\text {st }}$ cent. B.C (Bucallati - Kelly-Bucellati 1995/96, 1996, 1998, 2000, 2001, 2002, 2004; Dohmann-Pfälzner - Pfälzner 2000, 2001, 2002; Pfälzner 2010).

A number of smaller settlements has been identified in the area between Brak and Mozan: these are Tell Barri ca. 12 km north of Brak (Pecorella 2002; Pecorella, Pierobon-Benoit 2004), Tell Arbid half-way between Brak and Mozan (Bieliński 2000: 278, 2001: 318, 2002: 284, 291; Rutkowski 2006; Koliński 2012b; in print) and Tell Chagar Bazar, ca. $18 \mathrm{~km}$ west of Tell Arbid (McMahon et al. 2001; Tunca 2007). All of them are located in the central part of the Khabur Triangle, between valley of Jaghjagh and Wadi Hanzir, while no settlement of the same date is presently known in the western part of the area. However, a limited number of Post-Akkadian sites were identified by a survey in the area north to Tell Leilan (Arrivabeni 2010), a Post-Akkadian (or at least Late 
Akkadian) settlement was identified in the eastern part of Tell Hamukar (Gibson et al. 2002; Ur 2002b, 2010; Colantoni - Ur 2011), and there are hints at the presence of PostAkkadian layers at Tell Hawa (Ball 1990), Tell Taya (Reade 1968: 264), Tell Rimah in the Assyrian steppe (Postgate et al. 1997: 27-29), as well as at Tell Jikan (Oguchi 2003), Niniveh (McMahon 1998: 12-17; Gut et al. 2001) and at Assur on Tigris (Bär 2003: 38, 59-65). Towards the west, no settlement from this period is known from Tell Chuera, but at Kharab Seyyar, a site located in its close vicinity, there is evidence of PostAkkadian layers (Meyer et al. 2001). Finally, a number of flourishing settlements existed on the Euphrates, at Tell Selenkahiye (Meijer 2001: 25-27, Fig. 3.34; Schwartz 2001: 251-254), Tell Sweyhat, (Danti - Zettler 1998; Holland 2006: E-D periods) where the lower city enclosed by a defense wall was constructed during the $22^{\text {nd }}$ century (Danti Zettler 1998: 219, 223-224; Holland 2006: 21-26), Tell Bi'a (Strommenger - Kohlmeyer 2000: 42-69), Tell Ashara (Rouault 1996, 2001: 6-7) and, of course, Tell Hariri (Margueron 2004). There is no doubt that the Euphrates served as the source of water for irrigation agriculture on which the last group of settlements was based. Finally, further west there is a wave of new settlements on the arid steppe south of Jabbul Lake (Geyer Calvet 2001), including at least two urban sites, Rawda (Castel - Peltenburg 2007: 4-8, listing earlier reports on pp. 15-16) and Tell Sha'irat (al-Maqadisi 1995), all of them established around $2400 \mathrm{BC}$ and abandoned toward the end of the $21^{\text {st }}$ century (Castel 2007, 163-165).

Consequently, while there is regional abandonment observable in some parts of the Northern Mesopotamia, it would be an oversimplification to say that the settlement decrease occurred in the entire area. The situation changed in the $20^{\text {th }}$ century BC when, beside infrequent traces of human presence at some sites, there is hardly any evidence of a settlement in the entire north Mesopotamian littoral (Koliński 2007, 2012a).

\section{ENVIRONMENTAL STRESS}

The evidence of a natural disaster which, by triggering the aridifiaction climatic trend, was responsible for the settlement crisis has been recently reinterpreted as well. M.-A. Courty, whose research provided data quoted by Weiss in support of his reconstruction (cf. above), has significantly changed her position about the nature and date of this event. In a lecture presented at the $3^{\text {rd }}$ ICAANE in Paris in 2002 (Courty 2002) she stated that a catastrophe was caused by a small object from outer space entering the atmosphere and burning down/exploding in its lower strata. Also the date of the event was corrected, due to the fact that tehpra spherules of the same composition were identified on several sites as far west as Palestine. A series of samples for radio-carbon dating provided dates which cluster in the early part of the Early Jazirah IV/Akkadian period, i.e. about 150 years earlier than proposed by Weiss. 
The ancient climate and ancient distribution of environmental zones were recently subject to thorough consideration. While the original distribution of biotic provinces in the Northern Mesopotamia, reconstructed recently in a very suggestive way by Hillman (Moore et al. 2000: 43-91), had deteriorated a lot, especially as the result of extensive settlement and agricultural exploitation pursued from the mid- $3^{\text {rd }}$ millennium $\mathrm{BC}$ on, there is general agreement that the climatic conditions in the $3^{\text {rd }}$ millennium $\mathrm{BC}$ showed a trend towards aridification which reached its apex around 2100 BC (Bottema 1997: 495-506). The climate reconstruction is based on proxy data, mainly from palynological profiles (for instance Bottema 1997), and on modeling of long term climatic trends (for instance Bryson - Bryson 1997). This sef of data has two setbacks. First, there is no pollen profile for the entire Mesopotamia apart of the cores from Al-Hol/Khatuniyah Lake (Rösner - Schäbitz 1991) and Bouara saltpan (Gremmen - Bottema 1991), moreover both of them presented a relatively short (back till Roman period) or broken sequence. $^{2}$ As a result, reconstructions of ancient climate base on pollen samples recovered either in Iran (Zeribar) (van Zeist - Bottema 1977), in south-east Anatolia (Van: van Zeist - Woldering 1978; Söğütülü: van Zeist - Bottema 1991) or in Syro-Palestine (Ghab: Niklewski - van Zeist 1970; Huleh: Boruch - Bottema 1991; Kinneret Lake: Baruch 1986), that is areas located in different climatic and environmental zones and at a considerable distance from the Khabur Triangle.

A new viewpoint is represented thanks to the interpretation of results of a study of archaeobotanical remains collected at Tell Mozan (Riehl 2010; Deckers 2010). A noticeable increase of free-threshing wheat on expense of barley, typical for the earlier part of the third millennium BC, strongly suggests more favorable agricultural conditions during the Post-Akkadian period than it was previously assumed (Riehl 2010: 57-59, 65-69). ${ }^{3}$ Wheat needs more water and could be harvested only in stable moisture conditions, which contradicts the aridification hypothesis presented before. This observation is corroborated by a stable carbon $\left(\Delta^{13} \mathrm{C}\right)$ isotope record in analyzed cereal grains from various sites in northern Syria (Riehl 2008: Fig. 5; Riehl et al. 2008). This point of view is corroborated by the interpretation of wood samples from Tell Mozan, suggesting that towards the end of the $3^{\text {rd }}$ millennium BC in the area around Mozan an open woodland steppe was present, with a relatively high number of species interpreted as moisture indicators (Deckers 2010: 176-179, Fig. 25, Tab. 1).

Consequently, new sets of proxy data are badly needed to allow a more precise environmental reconstruction. There is hope that a new method for analyzing pollen encapsulated in the tooth enamel, already successfully used in Northern America, will allow to

\footnotetext{
${ }^{2}$ Palynological profile from Tell Hazna I, west of Tell Brak, has been published recently (Spiridionova 2004) but the methodology of this research is unclear.

${ }^{3}$ An analysis of grain samples from Post-Akkadian remains excavated by the present author in Sector P at Tell Abrid yielded very similar results, indicating an increase of reliability on free-threshing wheat in the PostAkkadian period, and an opposite tendency in the Middle Bronze II period, when barley became the dominating agricultural crop species once again (K. Wasylikowa, pers. comm.).
} 
obtain pollen data for Upper and Lower Mesopotamia as well. In the meantime, I would like to propose two other possible sources of proxy climatic data which have not been used to any extent, resulting from a specific approach to analysis of animal bone remains and of macro-remains of plants.

\begin{abstract}
ANIMAL BONES
Animal bone analyses focus on domesticated animal remains in order to get an insight into the economy and nutrition of ancient societies. But animal husbandry, because of human care, is conducted in conditions at least partly screened from the worst effects of the environment. Consequently, it can be hardly considered as indicative of climatic conditions. It is the opposite with wild animals. They are usually adapted to the very particular environmental conditions, defined as biotic zones and though some species are quite universal and can live in several zones there are some which are typical for a specific environment. This approach has been proposed by Helmer and others in their study of the environmental conditions at the advent of Neolithic era (Helmer et al. 1998) and was a subject of my study presented at the $4^{\text {th }}$ ICAANE in Berlin (Koliński Piątkowska-Małecka 2008).

Wild species can be divided into groups related to particular biotic zones. In the Near East, four such typical bio-zones are of much interest:

1) woodlands and mountain forests (Zones 2 and 3 by Hillman, cf. Moore et al. 2000: 50-58),

2) parklands (Zones 4 and by Hillman, cf. Moore et al. 2000: 58-61),

3) dry steppes and deserts (Zones 5 and 6 by Hillman, cf. Moore et al. 2000: 61-67), and

4) gallery forests of the river valleys (Zone 7 by Hillman, cf. Moore et al. 2000: 67-71).

Table $1^{4}$ lists wild species typical for each of these zones:
\end{abstract}

Table 1. List of wild species typical of the vegetation zones present in Northern Mesopotamia Tablica 1. Gatunki dzikich zwierząt typowe dla poszczególnych stref wegetacji w północnej Mezopotamii

\begin{tabular}{|c|l|l|l|}
\hline Forest and parkland & \multicolumn{1}{|c|}{ Moist steppe } & \multicolumn{1}{c|}{ Dry steppe and desert } & \multicolumn{1}{c|}{ Gallery forest } \\
\hline $\begin{array}{l}\text { bear, aurochs, boar, roe } \\
\text { deer, red deer, fallow deer, }\end{array}$ & $\begin{array}{l}\text { wild goat, gazelle, ona- } \\
\text { ger, donkey, ibex }\end{array}$ & $\begin{array}{l}\text { goitred gazelle, onager, } \\
\text { ostrich, donkey, ibex }\end{array}$ & $\begin{array}{l}\text { bear, aurochs, boar, red } \\
\text { deer, roe deer, fallow deer, }\end{array}$ \\
\hline
\end{tabular}

Forest and gallery forest feature a similar set of species, consequently, in humid areas, it is impossible to differentiate these zones. The situation in the arid areas of Mesopotamia, where the listed set of species needs to be linked to the gallery forest formation, is more favorable. Also, it is quite difficult to differentiate the humid steppe and dry steppe

${ }^{4}$ Based on Helmer et al. 2000: Tab. 2, and Gilbert 2002. 
zones - the only species which makes a clearly difference is the ostrich. Yet, the difference between woodland zones and steppe zones is clear: the set of animal species is nearly entirely different. It has been demonstrated by Cornelia Becker (Becker 1994, 2005/2006), who analyzed the appearance of elephant and beaver bones in the Near Eastern sites, that it is very likely that they were hunted locally and constituted an element of the local environment. This is probably true also with more frequently occurring species, though the animal's ability for ranging freely for food should be taken into account. Consequently, it is possible to use wild animals as an indicator of the local environmental conditions in a following way: two sets of species can be defined: these preferring woodland (humid) conditions (henceforth abbreviated WC) and these preferring steppe (arid) conditions (henceforth SC). A site featuring remains of both groups of species in the bone material will be most likely located in the area where both zones are present, though it will be impossible to tell which zone of woodland conditions is present in the vicinity of the site basing on the bones' identifications exclusively. Therefore, any substantial change of climate towards more arid or more humid conditions may be reflected by changes in the ratio of composition of both groups of wild animal species (defined above) at the site.

Now, let us compare composition of wild animal bones from sites located in the Khabur Triangle (for periods EJ III, EJ IV and EJ V) (Table 2).

Table 2. Recovery of wild animal bones on the archaeological sites from the Khabur Triangle area. (* Layers HS3-HS5 cover Early Jazirah IIIb and IVa (Early Akkadian) periods)

Tabela 2. Występowanie kości dzikich zwierząt na stanowiskach archeologicznych z terenu Trójkąta Chaburskiego (* Warstwy HS3-HS5 pochodzą z okresu Early Jazirach IIIb i IVa)

\begin{tabular}{|c|c|c|c|}
\hline Site & $\begin{array}{c}\text { EJ III } \\
\text { WC SC }\end{array}$ & $\begin{array}{c}\text { EJ IV } \\
\text { WC SC }\end{array}$ & $\begin{array}{c}\text { EJ V } \\
\text { WC SC }\end{array}$ \\
\hline 1 & 2 & 3 & 4 \\
\hline $\begin{array}{l}\text { Tell Arbid } \\
\text { (Piątkowska-Małecka - Smogorzewska 2010) }\end{array}$ & $\begin{array}{l}\text { Red deer }-3 \\
\text { Boar }-1 \\
\text { Equidae }-55 \\
\text { Gazelle }-1\end{array}$ & $\begin{array}{l}\text { Boar }-1 \\
\text { Equidae }-12\end{array}$ & $\begin{array}{l}\text { Cervidae }-15 \\
\text { Aurochs }-2 \\
\text { Boar }-2 \\
\text { Equidae }-87 \\
\text { Gazelle }-9\end{array}$ \\
\hline $\begin{array}{l}\text { Tell Arbid, Sector P (Piątkowska-Małecka, } \\
\text { pers. comm.) }\end{array}$ & - & - & $\begin{array}{l}\text { Red deer }-1 \\
\text { Equidae }-43 \\
\text { Gazelle }-1\end{array}$ \\
\hline $\begin{array}{l}\text { Tell Mozan } \\
\text { (Doll 2010) }\end{array}$ & $\begin{array}{l}\text { Aurochs }-3 \\
\text { Equidae }-85 \\
\text { Gazelle }-77\end{array}$ & $\begin{array}{l}\text { Aurochs }-1 \\
\text { Red deer }-1 \\
\text { Fallow deer }-1 \\
\text { Equidae }-16 \\
\text { Gazelle }-24\end{array}$ & $\begin{array}{l}\text { Aurochs }-1 \\
\text { Equidae }-26 \\
\text { Gazelle }-35\end{array}$ \\
\hline $\begin{array}{l}\text { Tell Beydar } \\
\text { (van Neer - de Cupere 2001) }\end{array}$ & $\begin{array}{l}\text { Equidae }-24 \\
\text { Gazelle }-9 \\
\text { Ostrich }-1\end{array}$ & $\begin{array}{l}\text { Red deer }-2 \\
\text { Roe deer }-1 \\
\text { Equidae }-26 \\
\text { Gazelle }-91\end{array}$ & - \\
\hline
\end{tabular}


cont. tab. 2

\begin{tabular}{|l|l|l|l|}
\hline \multicolumn{1}{|c|}{1} & \multicolumn{1}{c|}{2} & \multicolumn{1}{c|}{3} & \multicolumn{1}{c|}{4} \\
\hline $\begin{array}{l}\text { Tell Beydar } \\
\text { (Siracusano, in print) }\end{array}$ & Red deer -1 & $\begin{array}{l}\text { Equidae }-15 \\
\text { Gazelle }-44\end{array}$ & - \\
\hline Tell Leilan & Not published & Not published & - \\
\hline $\begin{array}{l}\text { Tell Brak FS } \\
\text { (Weber 2001) }\end{array}$ & n.d. & $\begin{array}{l}\text { Cervidae }-5 \\
\text { Equidae }-110 \\
\text { Gazelle }-8\end{array}$ & $\begin{array}{l}\text { Cervidae }-1 \\
\text { Equidae }-25 \\
\text { Gazelle }-3\end{array}$ \\
\hline $\begin{array}{l}\text { Tell Brak TC } \\
\text { (Weber 1999) }\end{array}$ & $\begin{array}{l}\text { Cervidae }-3 \\
\text { Equidae }-32 \\
\text { Gazelle }-23\end{array}$ & n.d. & n.d. \\
\hline $\begin{array}{l}\text { Tell Brak HS } \\
\text { (Dobney et al. 2004) }\end{array}$ & $\begin{array}{l}\text { Equidae -25* } \\
\text { Gazelle }-7\end{array}$ & $\begin{array}{l}\text { Equidae }-25^{*} \\
\text { Gazelle }-7\end{array}$ & n.d. \\
\hline
\end{tabular}

There is no evidence for a change in the pattern of occurrence of wild species typical for the woodland and the steppe zones at the listed sites. Both groups are present at Tell Arbid during the late $3^{\text {rd }}$ millennium $\mathrm{BC}$, although the steppe-preferring species are more numerous. The same situation is at Tell Brak and at Tell Mozan. Bones of aurochs and Cervidae species at both sites imply the presence of woodland areas in the central part of the Khabur triangle at that time. Moreover, as bones of animals of these groups continue in the Early Jazirah V period at Arbid, it may be assumed that there was no significant change in the environmental conditions during the EJ III-EJ V period. Yet, it has to be reminded that the evidence for the Akkadian period at Tell Arbid is not conclusive as the number of identified bones is too limited to be statistically significant (only 126 bones of this period have been identified). Tell Beydar clearly belongs to another zone, where species belonging to the woodland conditions species group are not present, neither during the EJ III, the EJ IV nor during the EJ V period. This may be interpreted as an indicator for stable environmental conditions, although, as a matter of fact, it only proves that there was no change towards more humid conditions in this area during the later $3^{\text {rd }}$ millennium BC. Stratigraphy of other listed sites did not cover the entire later part of $3^{\text {rd }}$ millennium $\mathrm{BC}$ in consequence they could not be used for the purpose of the present study.

\section{PLANT REMAINS}

Another possible source of proxy data on climate changes is constituted by plant remains. As it was already stated, there are no pollen diagrams available for the Khabur Triangle area. ${ }^{5}$ A new method, based on the analysis of pollens encapsulated in teeth

\footnotetext{
${ }^{5}$ Palynological sampling has in fact been undertaken at Tell Hazne, ca. $15 \mathrm{~km}$ west of Tell Brak. Samples were taken from the archaeological layers and consequently exclusively covered a period when the site was
} 
enamel has not been used in Mesopotamia yet, but it offers considerable prospects of enhancing the available set of data in the future.

In the meantime, macro-remains of plants constitute the main source of proxy data on the climate of the Khabur Triangle area. Considering seeds preserved mainly as charred remains, two groups may be easily distinguished: of domesticated crops and of wild plants, mainly weeds. Both these groups may provide information on environmental changes, though in different ways.

Agricultural conditions are reflected in size and weight of grains of domesticated crops. Simply speaking, the better conditions, the larger and heavier are the grains (cf Helbaek 1960: 193 for flax). On the one hand, grain measurements may be used as proof of irrigation agriculture in arid areas. A series of large grains would be present in all assemblages of remains, reflecting stable and water-rich conditions for the development of plants. On the other hand, they may provide a record of rain-fed agriculture conditions in areas where irrigation has not been used. Each year with shortcomings of rainfall will be clearly reflected by a reduction of dimensions and of weight of grains. A good case of this variability was presented by van Zeist in the case of Tell Bderi EJ III samples (van Zeist 2001: 119-120). One of these samples yielded grains of barley only $3 \mathrm{~mm}$ long on average, and 100 grains of carbonized matter weighed only $0.33 \mathrm{~g}$, while the other sample, consisting of grains measuring $5.81 \mathrm{~mm}$ on average, weighed four times more, i.e. $1.22 \mathrm{~g}$ for 100 grains. No grain measurements from the Khabur Triangle region are known to me, ${ }^{6}$ but it is obvious that for generalizations on agricultural regimes and conditions a long series of grain-rich samples is necessary, because only then "good" and "bad" years will be evidenced and their relative frequency may be calculated.

The other indicator is constituted by seeds of wild plants, mainly weeds co-existing on fields and around the fields. Though fields have to be considered as screened environment and the environmental changes may not be reflected by the weed composition in a direct way, they may be used as well as an indicator for agricultural conditions. Van Zeist, in his already quoted study of plant cultivation in the Khabur valley, considered the presence of seeds of Trigonella sp. as an indicator of rain-fed agricultural regimes conducted probably in the steppe beyond the limit of the river valley, while the lack of Trigonella seeds as indictor of irrigated or partly irrigated cultivation typical for the river valley (van Zeist 2001: 117). With a long series of samples it is also possible to determine possible changes of the weed composition. Analyses of wild plants seeds admix-

settled, ie. until mid-Third millennium BC. No data for the later period are available at the site (Spiridionova 2004).

${ }^{6} \mathrm{H}$. Helbaek has published measurements of barley grain from Tell Basmusian (Helbaek 1963). Grains retrieved from Isin-Larsa and Mitannian levels have a mean length of $6,65 \mathrm{~mm}$ in both these levels, ie. were slightly larger than those from Tell Bderi. This may reflect more favorable conditions of mountain river valley of Greater Zab.

${ }^{7}$ However, the size of grain may be influenced by numerous other factors. Therefore efficiency of this method needs to be carefully evaluated. 
ture to the grain samples collected at Tell Brak led to the conclusion that the conditions for agriculture in the vicinity of the site were relatively favorable and that there is no evidence of any significant change of climate either towards aridity or humidity (Charles - Bogaard 2001: 322, 325-326).

Of the two discussed sources of proxy data, the first, referring to grain size seems to be much more useful. However, one has to remember, that the size of grains may be strongly influenced by other factors.

\section{BIBLIOGRAPHY}

Arrivabeni M.

2010 Early Bronze Age Settlement in the Tell Leilan Region: A Report on the Ceramic Material of the 1995 Survey, Kaskal 8, s. 1-50.

Bär J.

2003 Die älteren Ischtar-Tempel in Assur, Wissenschaftlische Veröffentlischungen des Deutschen Orient Gesellschaft, Bd. 105, Berlin.

Ball W.

1990 Tell el-Hawa and the Development of the Urbanization in the Jazira, Al-Rafidain 11, s. 1-28.

Baruch U.

1986 Late Holocene Vegetational History of Lake Kinneret (Sea of Galilee), Israel, „Paléorient” 12 (2), s. 37-82.

Baruch U., Bottema S.

1991 Palynological evidence for climatic changes in the Levant ca. 17000-9000 BP, (w:) The Natufian Culture in the Levant, O. Bar Yosef, F. R. Valla (eds.), „International Monographs in Prehistory, Archaeological Series" 1, Ann Arbor, pp. 11-20.

Becker C.

1994 Elfenbein aus den syrischen Steppen? Gedanken zum Vorkommen von Elefanten in Nordsyrien im Spätholozän, (w:) Beiträge zur Archäozoologie und Prähistorischen Anthropologie, M. Kokabi, J. Wahl (eds.), Forschungen und Berichte zur Vor- und Frühgeschichte in Baden-Würtnberg 53, s. $169-181$.

2005/06 Small numbers, large potential - new prehistoric finds of elephant and beaver from the Khabur river/Syria, (w:) Homenaje a Jesús Altuna, S. C. Arazandi, Z. E. Donostia (eds.) MUNIBE 57/1, San Sebastian, s. 445-456.

Bieliński P.

2000 Tell Arbid. The Fourth Season, „Polish Archaeology in the Mediterranean”, vol. XI (Reports 1999), s. 273-284.

2001 Tell Arbid. Interim Report of the Fifth Season, „Polish Archaeology in the Mediterranean”, vol. XII (Reports 2000), s. 315-326.

2002 Tell Arbid, the Sixth Campaign of excavations. Preliminary Report, „Polish Archaeology in the Mediterranean", vol. XIII (Reports 2001), s. 279-294.

Bottema S.

1997 Third Millennium Climate in the Near East Based upon Pollen Evidence, (w:) Third Millennium BC Climate Change and Old World Collapse, H. Nüzhet Dalles, G. Kukla, H. Weiss (eds.), NATO ASI Series I: Global Environmental Change, vol. 49, Berlin, s. 489-515. 
Bryson R. U., Bryson R. A.

1997 High Resolution Simulations of Regional Holocene Climate: North Africa and the Near East, (w:) Third Millennium BC Climate Change and Old World Collapse, H. Nüzhet Dalles, G. Kukla, H. Weiss (eds.), NATO ASI Series I: Global Environmental Change, vol. 49, Berlin, s. 565-579.

Buccellati G., Kelly-Buccellati M.

1995/6 The Royal Storehouse of Urkesh: the glyptic evidence from the southwestern wing, „Archiv für Orientforschung" 42/43, s. 1-32.

1996 The seals of the King of Urkesh: evidence from the western wing of the royal storehouse, „Wiener Zeitschrift für Kunde des Morgenlandes" 86, s. 65-107.

1998a The courtiers of the Queen of Urkesh: evidence from the western wing of the royal storehouse AK, (w:) About Subartu, Studies devoted to Upper Mesopotamia, M. Lebeau (ed.), Subartu vol. IV, 2, Turnhout, s. 195-216.

1998b Urkesh and the Hurrians: Studies in Honour of Lloyd Cotsen, „Bibliotheca Mesopotamica”, vol. 26, Malibu.

2000 The Royal Palace of Urkesh, Report on the 12th Season at Tell Mozan/Urkesh: Excavations in Area AA, June-October 1999, „Mitteilungen der Deutschen Orient-Gesellschaft zu Berlin”, vol. 132, s. $133-183$.

2001 Überlegungen zur funktionellen und historischen Bestimmung des Königspalastes AP in Urkeš. Bericht über sdie 13. Kampagne in Tall Mozan/Urkeš: Ausgrabungen im Gebiet AA, Juni-August 2000, „Mitteilungen der Deutschen Orient-Gesellschaft zu Berlin”, vol. 133, s. 59-96.

2002 Die grosse Schnittstelle. Bericht über die 14. Kampagne in Tall Mozan/Urkeš: Ausgrabungen im Gebiet AA, Juni-Oktober 2001, „Mitteilungen der Deutschen Orient-Gesellschaft zu Berlin”, vol. 136, s. 103-130.

2004 Der monumentale Palasthof von Tall Mozan/Urkeš und die stratigraphishe Geschichte des ābi: Bericht über die 15. Kampagne 2002, „Mitteilungen der Deutschen Orient-Gesellschaft zu Berlin”, vol. 136, s. 13-39.

Castel C.

2007 L'abandon d'Al-Rawda (Syrie) à la fin du troisième millénaire; premières tentatives d'explication, (w:) Sociétés humaines et changement climatique à la fin du troisième millénaire: une crise a-t-elle eu lieu en Haute-Mésopotamie, Actes du Colloque de Lyon (5-8 décembre 2005), C. Marro et C. Kuzucuoğlu (eds.), Varia Anatolica vol. XIX, Paris, s. 159-178.

Castel C., Peltenburg E.

2007 Urbanism on the margins: third millennium BC Al-Rawda in the arid zone of Syria, „Antiquity” 81, s. $1-16$.

Charles M., Bogaard A.

2001 Third-millennium BC Charred Plant Remains from Tell Brak, (w:) Excavations at Tell Brak, vol. 2: Nagar in the third millennium BC, D. Oates, J. Oates, H. McDonald (eds.), „McDonald Institute Monographs", Cambridge, s. 301-326.

Colantoni C., Ur J.

2011 The Architecture and Pottery of a Late $3^{\text {rd }}$ Millennium BC Residential Quarter at Tell Hamoukar, Northeastern Syria, „Iraq” 73, s. 21-69.

Courty M.-A.

1994 Le cadre paléogéographique des occupations humaines dans la bassin du Haut-Khabour, Syrie du Nord-Est. Premiers résultats, „Paléorient” 20/1, s. 21-60.

1998 The soil record of an exceptional event at 4000 BP in the Middle East, (w:) Natural Catastrophes During the Bronze Age Civilisations, B.J. Peiser, Y. Palmer, M.E. Bailey (eds.), „British Archaeological Reports" 728, Oxford, s. 93-108. 
1999 The 4000 yr BP impact event: the birth of a scientific hypothesis, „The Observatory”, a review of Astronomy 119, s. 168-171.

2001 Evidence at Tell Brak for the Late EDIII/Early Akkadian Air Blast Event (4kyr BP), (w:) Excavations at Tell Brak, vol. 2: Nagar in the third millennium BC, D. Oates, J. Oates, H. McDonald (eds.), Cambridge, s. 367-372.

2002 Revisiting the nature, age, and social dimension of the Early Bronze Age natural catastrophe in the Ancient Near East, Lecture given at 3rd ICAANE, Paris, April 16 ${ }^{\text {th }}, 2002$.

Courty M.-A., Weiss H.

1997 The Scenario of Environmental Degradation in the Tell Leilan Region, NE Syria, During the Late Third Millennium Abrupt Climate Change, (w:) Third Millennium BC Climate Change and Old World Collapse, H. Nüzhet Dalles, G. Kukla, H. Weiss (eds.), NATO ASI Series I: Global Environmental Change, vol. 49, Berlin, s. 107-147.

Danti M. D., Zettler R. L.

1998 The Evolution of the Tell es-Sweyhat (Syria) Settlement System in the Third Millennium B.C., (w:) Espace naturel, espace habité en Syrie du Nord (10e-2e millénaires av. J.-C.), M. Fortin, O. Aurenche (eds.), BSMS 33/TMO 28, Québec-Lyon, s. 209-227.

Deckers K.

2010 Anthracological Research at the Early to Middle Bronze Age Settlement of Tell Mozan, (w:) K. Deckers, M. Doll, P. Pfälzner, S. Riehl, Development of the Environment, Subsistence and Settlement of the city of Urkeš and its Region, Studien zur Urbanisierung Nordmesopotamiens Serie A, Bd. 3, Wiesbaden, s. 159-190.

Dobney K., Jaques D., van Neer W.

2004 Diet, Economy and Status: Evidence from the Animal Bones, (w:) Excavations at Tell Brak, vol. 4: Exploring an Upper Mesopotamian regional center 1994-1996, Matthews R. (ed.), Cambridge, s. 417-430.

Dohmann-Pfälzner H., Pfälzner P.

2000 Ausgrabungen der Deutschen Orient-Gesselschaft in der zentralen Oberstadt von Tall Mozan/Urkeš. Bericht über die in Kooperation mit dem IIMAS durchgeführte Kampagne 1999, „Mitteilungen der Deutschen Orient-Gesellschaft zu Berlin”, vol. 132, s. 185-228.

2001 Ausgrabungen der Deutschen Orient-Gesselschaft in der zentralen Oberstadt von Tall Mozan/Urkeš. Bericht über die in Kooperation mit dem IIMAS durchgeführte Kampagne 2000, „Mitteilungen der Deutschen Orient-Gesellschaft zu Berlin", vol. 133, s. 97-140.

2002 Ausgrabungen der Deutschen Orient-Gesselschaft in der zentralen Oberstadt von Tall Mozan/Urkeš. Bericht über die in Kooperation mit dem IIMAS durchgeführte Kampagne 2001, „Mitteilungen der Deutschen Orient-Gesellschaft zu Berlin”, vol. 134, s. 149-192.

Doll M.

2010 Meat, Traction, Wool: Urban Livestock in Tell Mozan, (w:) K. Deckers, M. Doll, P. Pfälzner, S. Riehl, Development of the Environment, Subsistence and Settlement of the City of Urkeš and its Region, Studien zur Urbanisierung Nordmesopotamiens Serie A, Bd. 3, Wiesbaden, s. 191-359.

Geyer B., Calvet Y.

2001 Les steppes arides de la Syrie du Nord au Bronze Ancien au „la premiere conquête de l'est”, (w:) Conquête de la steppe et appropritation des terres sur les marges arides du Crescent Fertile, B. Geyer (ed.), „Travaux de la Maison d'Orient Méditerraneen” 36, Lyon, s. 55-67.

Gibson McG., al-Azm A., Reichel C., Quntar S., Franke J. A., Khalidi L., Hritz C., Altaweel M., Coyle C., Colantoni C., Tenney J., Abdulaziz Gh., Hartnell T.

2002 Hamoukar: A Summary of Three Seasons of Excavation, „Akkadica” 123, s. 11-14.

Gilbert A.

2002 The Native Fauna of the Ancient Near East, (w:) A History of the Animal World in the Ancient Near East, B. J. Collins (ed.), Handbuch der Orientalistik, vol. 64, Leiden-Boston-Köln, s. 3-59. 
Gremmen W. H. E., Bottema S.

1991 Palynological Investigations in the Syrian Gazira, (w:) Die rezente Umwelt von Tell Šèh Hamad und Daten zur Umweltrekonstruktion der assyrischen Stadt Dūr-Katlimmu, H. Kühne (ed.), Berlin, s. $105-116$.

Gut R., Reade J., Boehmer R.-M.

2001 Ninive - das späte 3. Jahrtausend v. Chr., (w:) Beiträge zur vorderasiatischen Archäologie Winfried Orthmann gewidemt, J.-W. Mayer, M. Novák, A. Pruss (eds.), Frankfurt am Main, s. 74-129.

Helbaek H.

1960 Ecological Effects of Irrigation in Ancient Mesopotamia, „Iraq”22, s. 186-196.

1963 Isin-Larsan and Horian Food Remains at Tell Bazmosian in the Dokan Valley, „Sumer” 19, s. $27-35$.

Helmer D., Roitel V., Saña M., Willcox G.

1998 Interprétations environnmentales des donnes archéozoologiques et archéobotaniques en Syrie du Nord de 16000 à 7000 BP, et les débuts de la domestication des plantes et des animaux, (w:) Espace naturel, espace habité en Syrie du Nord (10e-2e millénaires av. J.-C.), M. Fortin, O. Aurenche (eds.), BSMS 33/TMO 28, Québec-Lyon, s. 9-33.

Holland T.

2006 Archaeology of the Bronze Age, Hellenistic, and Roman Remains at an Ancient Town on the Euphrates River, Excavations at Tell es-Sweyhat, vol. 2, OIP 125, Chicago.

Koliński R.

2007 The Upper Khabur Region in the Second Part of the Third Millennium BC, „Altorientalische Forschungen" 34, s. 342-369.

2012a $20^{\text {th }}$ century BC in the Khabur Triangle region and the advent of the Old Assyrian Trade with Anatolia, (w:) The Archaeology of the Upper Mesopotamian Piedmont in the Second Millennium BC, D. Bonatz (ed.), Berlin.

2012b Tell Arbid. Adam Mickiewicz University of Poznan Excavations in Sector P, Spring Season of 2008, „Polish Archaeology in Mediterranean”, Reports 2008, vol. XX, pp. 301-317.

[in print] Tell Arbid. Adam Mickiewicz University of Poznan Excavations in Sector P, Spring Season of 2009, „Polish Archaeology in Mediterranean”, Reports 2009, vol. XXI.

Koliński R., Piątkowska-Małecka J.

2008 Animals in the Steppe: Patterns of Animal Husbandry as a Reflection of Changing Environmental Conditions in the Khabur Triangle, (w:) Proceedings of the 4th ICAANE, 29 March - 3 April 2004, Freie Universität Berlin, vol. 1, H. Kühne, R. M. Czihon, F. J. Kreppner (eds.), Wiesbaden, s. 115-128.

Mallowan M. E. L.

1937 Excavations at Chagar Bazar, and an Archaeological Survey of the Khabur Region, Second Campaign, 1936, „Iraq” 4, s. 91-177.

1947 Excavations at Brak and Chagar Bazar, „Iraq” 9, s. 1-259.

al-Maqdissi M.

1995 Tell Sha'irat (region de Homs), „Syria” 72, s. 196-198.

Margueron J.-C1.

2004 Mari, Métropole de l'Euphrate, Paris.

Matthews R. J. (ed.)

2003 Excavations at Tell Brak, vol. 4: Exploring an Upper Mesopotamian Regional Centre, 1994-1996, Cambridge.

Mac Mahon A.

1998 The Kuyunjik Gully Sounding, Niniveh 1989 \& 1990 Seasons, „Al-Rafidain” 19, s. 1-32.

Mac Mahon A., Tunca Ö., Baghdo A.

2001 New Excavations at Tell Chagar Bazar, 1999-2000, „Iraq”63, s. 201-222. 
Mejier D.

2001 Architecture and Stratigraphy, (w:) Selenkahiye, Final Report on the University of Chicago and University of Amsterdam Excavations in the Tabqa Reservoir, Northern Syria, 1967-75, M. van Loon (ed.), PIHANS XCI, Istanbul, s. 25-112.

Meyer J.-W., al-Khalaf M., Breitwieser Ch., Doerner S., Hampelmann R., Würz M., Zysek A.

2001 Die dritte Grabungskampagne in Kharab Seyyar 2000, „Mitteilungen der Deutschen OrientGesellschaft zu Berlin", vol. 133, s. 199-224.

Moore A. M. T., Hillman G., Legge A. J.

2000 Village on the Euphrates. From foraging to farming at Abu Hureyra, Oxford.

van Neer W., de Cupere B.

2001 Faunal remains from Tell Beydar (excavation seasons 1992-1996 and 1997 partim), (w:) Tell Beydar: Environmental and Technical Studies, K. van Lerberghe, G. Voet (eds.), Subartu 6, Turnhout, s. 69-95.

Niklevski J., van Zeist W.

1970 A late Quaternary pollen diagram from Northwestern Syria, „Acta Botanica Neerlandica” 19, s. 737-754.

Nüzhet Dalles H., Kukla G., Weiss H. (eds.)

1997 Third Millennium BC Climate Change and Old World Collapse, NATO ASI Series I: Global Environmental Change, vol. 49, Berlin.

Oates J.

2001 The Third Millennium Pottery, (w:) Excavations at Tell Brak, vol. 2: Nagar in the Third Millennium $B C$, D. Oates, J. Oates, H. McDonald (eds.), Cambridge, s. 151-194.

Oates D., Oates J.

2001 Archaeological Reconstruction and Historical Commentary, (w:) Excavations at Tell Brak, vol. 2: Nagar in the Third Millennium BC, D. Oates, J. Oates, H. McDonald (eds.), Cambridge, s. 279-396.

Oguchi H

$200320^{\text {th }}$ Century B. C. North Mesopotamia: An Archaeological Dilemma, „Rafidain” 24, s. 83-100.

Owen D. I.

1992 Syrians in Sumerian Sources from the Ur III Period, (w:) New Horizons in the Study of Ancient Syria, M. Chavalas, J. L. Hayes (eds.), „Bibliotheca Mesopotamica”, vol. 25, Malibu, s. 107-176.

Pecorella P. E.

2002 La missione archaeologica italiana a Tell Barri (Syria) - 2001, „Orient Express” 3, s. 67-73.

Pecorella P. E., Pierobon-Benoit R.

2004 Tell Barri/Kahat. La Campagna del 2001. Relazione preliminare, Firenze.

Piątkowska-Małecka J., Koliński R.

2006 Animal Remains from Tell Arbid (North-east Syria), (w:) Beiträge zur Archäozoologie und Prähistorischen Anthropologie, Bd. V, N. Benecke (ed.), Ludwigsdorf, s. 22-31.

Piątkowska-Małecka J., Smogorzewska A.

2010 Animal Economy at Tell Arbid, north-east Syria, in the third millennium BC, „Bioarchaeology of the Near East" 4, s. 25-43.

Pfälzner P.

2010 Introduction and Synthesis: Urban Development and Ecology at Tell Mozan, (w:) K. Deckers, M. Doll, P. Pfälzner, S. Riehl, Development of the Environment, Subsistence and Settlement of the city of Urkeš and its Region, „Studien zur Urbanisierung Nordmesopotamiens” Serie A, Bd. 3, Wiesbaden, s. $1-12$

Postgate C., Oates D., Oates J.

1997 The Excavations at Tell al Rimah: The Pottery, „Iraq Archaeological Reports”, vol. 4, Warminster: The British School of Archaeology in Iraq. 
Reade J

1968 Tell Taya (1967): Summary Report, „Iraq” 30, s. 234-264.

1982 Tell Taya, (w:) Fifty Years of Mesopotamian Discovery, J. Curtis (ed.), London, s. 72-78.

Riehl S.

2008 Climate and agriculture in the ancient Near East: a synthesis of the archaeobotanical and stable carbon isotope evidence, ,Vegetation History and Archaeobotany” 17, suppl 1, s. 43-51.

2010 Plant Production in a Changing Environment: The Archaeobotanical Remains from Tell Mozan, (w:) K. Deckers, M. Doll, P. Pfälzner, S. Riehl, Development of the Environment, Subsistence and Settlement of the city of Urkeš and its Region, Studien zur Urbanisierung Nordmesopotamiens Serie A, Bd. 3, Wiesbaden, s. 13-158.

Rieh1 S., Bryson R. A., Pustovoyov K.

2008 Changing Growing Conditions for Crops During the Near Eastern Bronze Age (3000-1200 BC): The stable carbon isotope evidence, ,Journal of Archaeological Science” 35, s. 1011-1022.

Rösner U., Schäbitz F.

1991 Palynological and Sedimentological Evidence for the Historic Environment of Khatouniye, Eastern Djezire, „Paléorient” 17/1, s. 77-87.

Rouault O

1996 Terqa et l'époque de Shakkanakku, (w:) Tablettes et images aux pays de Sumer et d'Akkad. Mélanges offerts à Monsieur H. Limet, Ö. Tunca, D. Deheselle (eds.), Liège, s. 105-109.

2001 Terqa et sa région (6e - 1er millénaires av. J.-C.), „Akkadica” 122, s. 1-26.

Rutkowski $€$.

2006 Górna Mezopotamia na przełomie III I II tysiąclecia p.n.e. Analiza postakadyjskiego materiału ceramicznego z Tell Arbid (Upper Mesopotamia at the Turn of the 3rd Millennium BC. Analysis of the Post-Akkadian pottery assemblages from Tell Arbid), unpublished Ph. D. thesis (in Polish), Institute of Archaeology, Warsaw University, Warsaw.

Schwartz G. M.

2001 The Pottery from Selenkahiye 1972, 1974, and 1975, (w:) Selenkahiye, Final Report on the University of Chicago and University of Amsterdam Excavations in the Tabqa Reservoir, Northern Syria, 1967-75, M. van Loon (ed.), PIHANS XCI, Istanbul, s. 223-340.

Siracusano $\mathrm{G}$.

[in press] Third Millennium Fauna at Tell Beydar, Syria, (w:) Tell Beydar: Environmental and Technological Studies 2, L. Milano (ed.), Subartu 21, Turnhout.

Spiridionova E. A.

2004 Rezultaty palinologičeskich issledovanii Tell Hazny I (in Russian), (w:) Tell Hazna I. Kultovoadministrativnyj centr IV-III tys. do n.e. v severno-vostočnej Sirii, P. M. Munchaev, H. J. Merpert, Sz. H. Amirov (eds.),Moscov, s. 441-462.

Strommenger E., Kohlmeyer K.

2000 Ausgrabungen in Tall Bi'a Tuttull - III: Die Schichten des 3. Jahrtausends v. Chr. Im Zentralhügel E, „Wissenschaftlische Veröfentlischungen des Deutschen Orient-Gesellschaft”, vol. 101.

Tunca Ö., Mac Mahon A., Baghdo A.

2007 Chagar Bazar (Syrie) II. Les vestiges post-akkadiens du chantier D et études diverses. Leuven.

$\mathrm{Ur} \mathrm{J}$.

2002 Settlement and Landscape in Northern Mesopotamia: The Tell Hamoukar Survey 2000-2001, „Akkadica" 103, s. 57-88.

2010 Urbanism and Cultural landscapes in Northeastern Syria: The Tell Hamoukar Survey, 1999-2001, „Oriental Institute Publications”, vol. 137, Chicago.

van Zeist W.

2001 Third to First Millennium BC Plant Cultivation on the Khabur, North-Eastern Syria, „Palaeohistoria” 41/42, s. 111-125. 
van Zeist W., Bottema S.

1977 Palynological Investigations in the Western Iran, „Palaeohistoria” 19, s. 19-95.

1991 Late Quaternary Vegetation of the Near East, Beihefte zum TAVO, Reihe A, Nr. 18, Wiesbaden. van Zeist W., Woldering $\mathrm{H}$.

1978 A Postglacial Pollen Diagram from Lake Van in East Anatolia, „Review of Paleobotany and Palinology" 26, s. 249-276.

Weber J.

1999 Faunal Remains, (w:) Excavations at Tell Brak 1998. Preliminary Report, G. Emberling et al., „Iraq” 61, s. 26-30.

2001 A Preliminary Assessment of Akkadian and Post-Akkadian Animal Exploitation at Tell Brak, (w:) Excavations at Tell Brak, vol. 2: Nagar in the Third Millennium BC, D. Oates, J. Oates, H. McDonald (eds.), Cambridge, s. 345-350.

Weiss $\mathrm{H}$.

1985 Tell Leilan and Shubat-Enlil, „MARI, Annales des Recherches Interdisciplinaires” 5, s. $269-292$.

1986 The Origins of Tell Leilan and the Conquest of Space in Third Millennium BC, (w:) The Origins of Cities in Dry-Farming Syria and Mesopotamia in the Third Millennium BC, H. Weiss (ed.), Guilford, s. 71-107.

1990a 'Civilizing' the Habur Plains: Mid-Third Millennium State Formation at Tell Leilan, (w:) Resurrecting the Past. A Joint Tribute to Adnan Bounni, P. Matthiae, M. van Loon, H. Weiss (eds.), PIHANS LXVII, Istanbul, s. 387-407.

1990b Tell Leilan 1989: New Data for Mid-Third Millennium Urbanization and State Formation, „Mitteilungen der Deutschen Orient-Gesellschaft zu Berlin”, vol. 122, s. 193-218.

1990c Third Millennium Urbanization: A Perspective from Tell Leilan, (w:) Tall al-Hamīdīya 2, S. Eichler, M. Wäfler, D. Warburton (eds.), Freiburg, s. 159-166.

2000a Causality and Chance: Late Third Millennium BC Collapse in Southwest Asia, (w:) La Djéziré et l'Euphrate syriens de la protohistoire à la fin du Ile millénaire av. J.-C. Tendances dans l'interprétation historique des données nouvelles, O. Rouault, M. Wäfler (eds.), Subartu 7, Turnhout, s. 207-219.

2000b Beyond Younger Dryas: Collapse as Adaptation to Abrupt Climate Change in Ancient West Asia and the Eastern Mediterranean, (w:) Environmntal Disaster and the Archaeology of Human Response, G. Bawden, R. M. Reycraft (eds.), Maxwell Museum of Anthropology, „Anthropological Papers" No. 7, Albuquerque: Academic Press, s. 75-98.

2002 Unfinished Business: Akkadian Collapse at Tell Leilan, a lecture given at $3^{\text {rd }}$ ICAANE, Paris, April $18^{\text {th }}, 2002$.

Weiss H., Bradley R. S.

2001 What Drives Societal Collapse?, „Science” 291, s. 609-610.

Weiss H., Courty M.-A.

1993 The Genesis and Collapse of the Akkadian Empire, (w:) Akkad: The First World Empire, M. Liverani (ed.), Padua, s. 131-155.

Weiss H., Courty M.-A., Wetterstorm W., Guichard F., Senior L., Meadow R., Curnow A.

1993 The Genesis and Collapse of the Third Millennium North Mesopotamian Civilization, „Science”261, s. $995-1004$.

Wilhelm G.

1998 Die Inschrift des Tišatal von Urkeš, (w:) Urkesh and the Hurrians: Studies in Honor of Lloyd Cotsen, G. Buccellati, M. Kelly-Buccellati (eds.), „Bibliotheca Mesopotamica”, vol. 26, Malibu, s. 117-145.

Wilkinson T. J.

1997 Environmental Fluctuations, Agricultural Production and Collapse: A View from Bronze Age Upper Mesopotamia, (w:) Third Millennium BC Climate Change and Old World Collapse, H. Nüzhet 
Dalles, G. Kukla, H. Weiss (eds.), NATO ASI Series I: Global Environmental Change, vol. 49, Berlin, s. 67-106.

2003 Archaeological Landscapes of the Near East, Tucson.

Zettler R. L.

2003 Reconstructing the World of Ancient Mesopotamia: Divided Beginnings and Holistic History, ,Journal of Economic and Social History of Orient" 46, 1, s. 3-45.

\section{O ZIARNIE, KOŚCIACH I KRYZYSIE OSADNICZYM NAD HABUREM}

\section{Streszczenie}

Amerykański archeolog Harvey Weiss, badający stanowisko Tell Leilan w północno-wschodniej Syrii, zaproponował w 1993 r. katastroficzną wizję kryzysu osadnictwa na terenie północnej Mezopotamii u schyłku III tysiąclecia p.n.e. Opuszczenie wszystkich zamieszkanych wcześniej stanowisk miało być wynikiem gwałtowanego pogorszenia warunków środowiskowych spowodowanego emisją pyłu i dymu z wybuchającego na terenie Bliskiego Wschodu wulkanu.

Już w chwili ogłoszenia hipotezy było jasne, że osadnictwo nie znikło z północnej Mezopotamii - tak ważne miasta, jak: Mari, Mozan czy Nagar istniały bez przerwy - a badania wykopaliskowe ostatnich 15 lat dostarczyły licznych przykładów istniejących osad nawet w bezpośredniej bliskości Tell Leilan (Fig. 1). Podano w wątpliwość także przyczynę pogorszenia warunków do prowadzenia upraw, choć samego faktu zaistnienia tego typu kryzysu nie zakwestionowano.

Ocena fluktuacji dawnego klimatu Mezopotamii jest bardzo trudna - przede wszystkim dlatego, że nie dysponujemy bezpośrednimi wskaźnikami pozwalającymi na wgląd w dawne warunki klimatyczne i ich fluktuacje. W tej sytuacji badacze muszą posługiwać się albo danymi sąsiadujących regionów, albo wskazówkami pośrednimi. Z najnowszych opublikowanych danych wynika, że w okresie domniemanego kryzysu osadniczego warunki naturalne nie tylko nie uległy pogorszeniu, ale wręcz się poprawiły. Zdecydowana zmiana na niekorzyść dokonała się dopiero w XX w. p.n.e.

Obecnie nie sposób zaprezentować przekonującej rekonstrukcji przyczyn nastania kryzysu osadniczego w północnej Mezopotamii. Nadzieja w dalszych badaniach, przede wszystkim opartych na nowych danych - na przykład w ocenie warunków środowiskowych na podstawie kości dzikich zwierząt znajdowanych w zespołach postkonsumpcyjnych materiałów kostnych, oraz w wielkości ziaren zbóż i występujących zespołach szczątków roślinnych nasion i fragmentów roślin dzikich. 